\title{
REKAYASA PERANGKAT LUNAK SISTEM INFORMASI GEOGRAFIS (SIG) TATA LETAK PENYEDIA SARANA PENANGGULANGAN KEBAKARAN
}

\author{
Andi Usri Usman', Syaechurodji ${ }^{2}$ \\ Dosen Fakultas Ilmu Komputer, Universitas Banten Jaya \\ Jl. Syeh Nawawi Al-Bantani, Boru, Serang Banten \\ Email: andiusriusman@unbaja.ac.id ${ }^{1}$, syaechurodji@unbaja.ac.id ${ }^{2}$
}

\begin{abstract}
The fire department is a government agency that handles fire and fire prevention. After conducting research, quite a lot of activities or activities found in the fire department, especially in the field of fire prevention, one of which is managing data about the layout of providers of fire prevention facilities so that they can be useful information and help in fire prevention efforts by postal officers extinguisher. But in doing so, fire department officials find difficulties such as the difficulty of finding the location of the supporting aspects, misinformation of the layout of supporting facilities so that it takes a lot of time, and demographic data has not been thoroughly integrated and centralized with the main database. making it difficult to update and allow errors. Geographical Information System (GIS) layout of providers of web-based fire prevention facilities is expected to provide solutions to the problems above, thus facilitating the process of managing information on the layout of providers of fire prevention facilities.
\end{abstract}

Keywords: Geographic Information Systems, Software Engineering

\section{PENDAHULUAN}

Pada proses pencarian data sebagai informasi tata letak penyedia sarana pendukung dalam upaya penanggulangan kebakaran seperti letak pos pemadam kebakaran, hydrant, sumber air, Satuan Relawan Pemadam Kebakaran (SATLAKAR) dan lainnya masih memerlukan waktu yang cukup lama. Untuk melakukan hal-hal tersebut pegawai kantor pemadam kebakaran menemukan kesulitan seperti susah mencari letak titik aspek pendukung tersebut, salah dalam mendapatkan informasi tata letak penyedia sarana pendukung sehingga menghabiskan banyak waktu, dan data demografi belum terintegrasi secara menyeluruh dan terpusat dengan database utama, sehingga menyulitkan untuk mengupdate dan memungkinkan terjadi kesalahan.

Demografi adalah program pemetaan dari suatu wilayah yang berfungsi untuk memudahkan seorang user dalam melihat tata letak dari suatu wilayah tersebut sehingga user dapat mengetahui secara jelas dimana letak wilayah yang 
dicari dan juga informasi penting mengenai wilayah tersebut. Informasi dan data demografi letak titik aspek pendukung dapat langsung diketahui dengan media internet dalam bentuk website.

Perangkat lunak Sistem Informasi Geografis (SIG) memungkinkan pengguna untuk menampilkan data spasial dengan format yang sesuai. Sebagai hasilnya, interpretasi data spasial menjadi lebih mudah untuk dipahami. Namun tidak semua orang mempunyai akses ke SIG dan mau menggunakan waktunya untuk menggunakan perangkat lunak SIG secara efisien. Beberapa organisasi pemerintahan maupun non pemerintahan mempunyai kebutuhan untuk menyebarkan peta dan tool untuk pemrosesannya kepada pengguna tanpa dibatasi oleh waktu dan lokasi. SIG berbasis web menjadi cara yang mudah dan murah untuk melakukan penyebaran data geospasial dan sebagai tool untuk pemrosesan data geospasial.

Bebrapa hal menjadi kendala dalam pelaksanaan penelitian mengenai tata letak penyedia sarana penanggulangan kebakaran seperti :

1. Informasi demografi yang berupa letak penyedia sarana pendukung untuk penanggulangan kebakaran di setiap pos pemadam kebakaran yang berada di masing-masing daerah belum terintegrasi dengan database dalam bentuk database induk, sehingga pos pemadam kebakaran cukup lama untuk mendapatkan informasi demografi pos pemadam kebakaran setempat ketika sedang bertugas di daerah lain.

2. Dalam mendapatkan informasi letak penyedia sarana pendukung untuk penanggulangan kebakaran menghabiskan banyak waktu, karena sistem yang berjalan belum adanya GIS yang berbasis web, Sehingga informasi letak penyedia sarana pendukung untuk penanggulangan kebakaran tidak dapat di akses secara luas oleh masing-masing pos pemadam kebakaran, dan pembuatan laporan informasi sarana pendukung penanggulangan kebakaran membutuhkan waktu yang lama.

\section{METODE PENELITIAN}

Metode yang digunakan dalam penelitian ini menggunakan Arsitektur SIG berbasis Web di mana dalam menjalankan tugas-tugas analisis SIG, SIG berbasis web mirip dengan tipe arsitektur tiga tingkat client server. Pemrosesan data 
geograsfis dibagi menjadi bagian yaitu di sisi server dan di sisi client. Pada bagian Client biasanya adalah suatu web browser, sedangkan bagian server terdiri dari Web Server, aplikasi SIG berbasis web dan basis data, seperti terlihat pada gambar 1 (Helali, 2010).

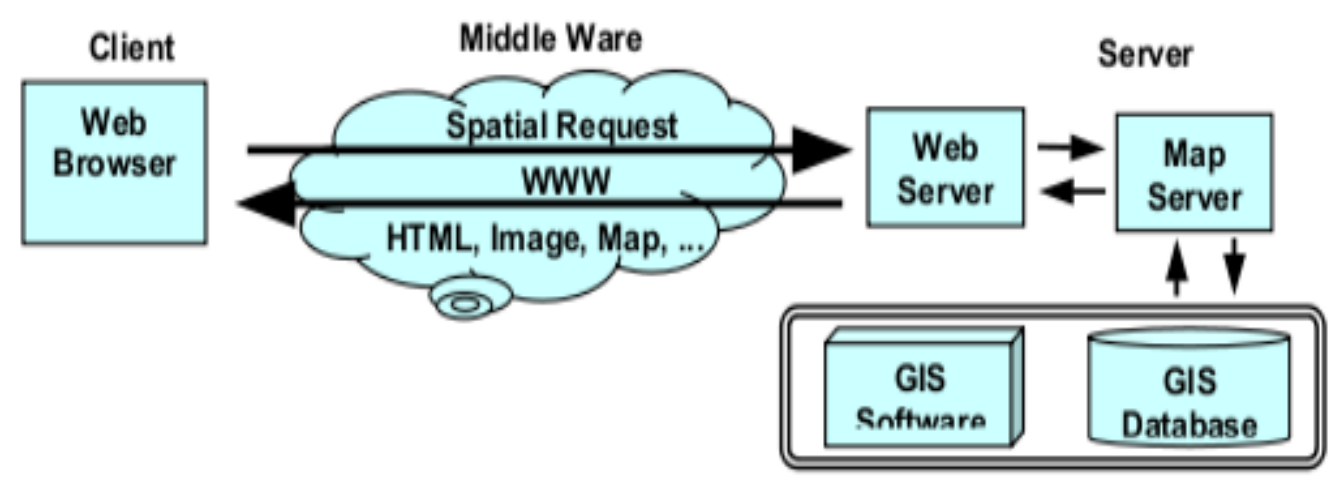

\section{Gambar 1. Arsitektur SIG Berbasis Web}

Model jaringan ini dikenal luas dalam organisasi, dimana beberapa komputer bertindak sebagai server dan lainnya bertindak sebagai klien. Server mempunyai hak untuk menjalankan aplikasi SIG dan menambahkan sebuah antarmuka di sisi client dan suatu middleware di sisi server untuk berkomunikasi antara klien dan aplikasi SIG. Perkembangan terbaru dalam pemrograman berorientasi obyek memungkinkan untuk memproduksi komponen perangkat lunak, dan mengirimnya ke Client sebelum menjalankannya di mesin Client, seperti kelas Java, komponen ActiveX dan plug-in. Model ini disebut thick client GIS. Pada arsitektur thick client, mesin akan melakukan pekerjaan pemrosesan secara lokal. Baik thin maupun thick client system memiliki beberapa keuntungan dan kelemahan, tetapi mereka bukan merupakan solusi terbaik dalam hal memanfaatkan sumber daya jaringan.

Mengembangkan sebuah SIG berbasis web berbeda dengan sekedar membeli perangkat keras dan perangkat lunak yang sesuai. Beberapa strategi telah diusulkan untuk memberikan keberhasilan dalam implementasinya (Alesheikh \& Helali 2010). Strategi implementasi SIG ini telah diuji secara ilmiah dan telah dimodifikasi sehingga kebutuhan suatu pelaksanaan proyek pengembagan SIG berbasis dapat dipenuhi dengan biaya dan waktu yang minimum. Pada gambar 2 
ditunjukkan siklus pengembangan SIG berbasis web yang digambarkan dalam 8 kegiatan utama, dimulai dengan analisis kebutuhan dan berakhir dengan penggunaan dan pemeliharaan sistem SIG berbasis web (Alesheikh, Helali \& Behroz, 2010).

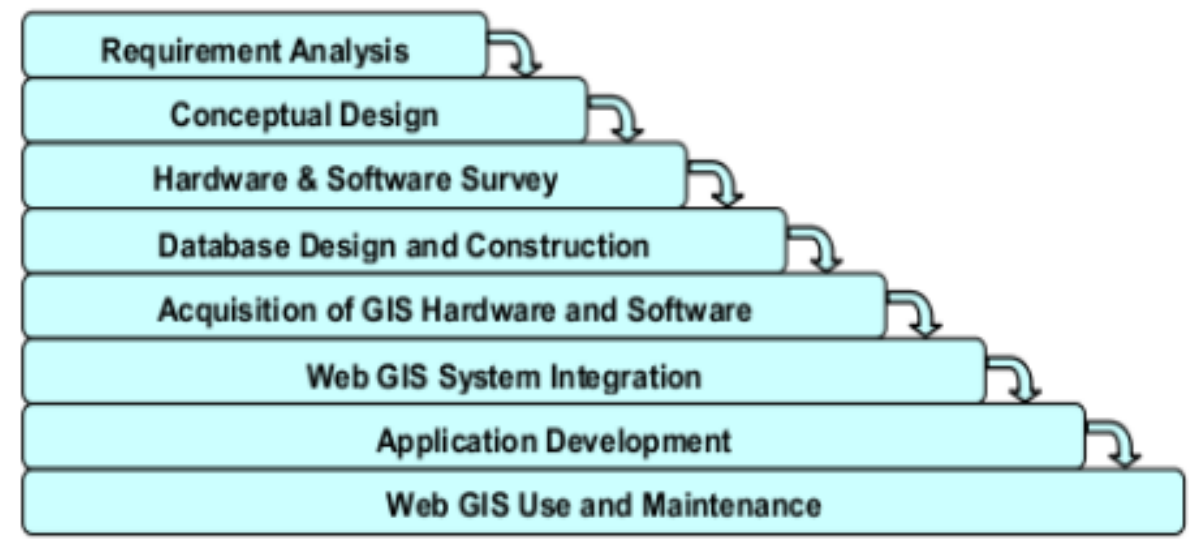

\section{Gambar 2. Siklus Pengembangan SIG Berbasis Web}

Penjelasan dari tahapan-tahapan pengembangan SIG berbasis web adalah sebagai berikut :

1. Analisa Kebutuhan (Requirement Analysis)

Di dalam tahapan ini harus ditentukan terlebih dahulu tujuan yang ingin dicapai dari sistem yang akan dibuat. Langkah analisis kebutuhan dapat dilakukan melalui wawancara dengan calon pengguna. Langkah ini menghasilkan dua bagian penting dari informasi:

a. Fungsi-fungsi yang diperlukan. Fungsi-fungsi yang diperlukan adalah fungsi visualisasi dasar seperti Pan, Zoom, dan fungsi lain yang lebih maju seperti identifikasi objek, query spasial, dan jalan terpendek.

b. Data geografis yang diperlukan. Informasi yang diperoleh dalam kegiatan analisis kebutuhan akan dilanjutkan ketahap berikutnya yaitu disain konseptual SIG.

2. Disain konseptual (Conceptual Design)

Setelah data yang dibutuhkan telah diidentifikasi, dirancanglah model data yang diwujudkan dalam diagram relasi entitas (Entity Relationship Diagram).

3. Survey terhadap Ketersediaan Perangkat Keras dan Perangkat Lunak (Hardware and Software Survey). 
Pemilihan perangkat lunak yang cocok merupakan langkah penting dalam kesuksesan tahapan implementasi. Perangkat Lunak dievaluasi pada fungsionalitas dan kinerja, dan independen dari hardware dan sistem operasi.

4. Perancangan Basisdata dan Konstruksi (Database Design and Construction) Tujuan utama pada tahapan ini adalah untuk menentukan "bagaimana" Web GIS merancang kebutuhan aplikasi yang diperlukan. Perancangan basisdata meliputi bagaiman mendefinisikan bagaimana grafis akan dilambangkan (yaitu warna, berat, ukuran, simbol, dll), bagaimana bentuk struktur file grafis, bagaimana bentuk struktur atribut file non grafis, layer mana yang aktif, dalam skala apa layer yang harus ditampilkan, bagaimana produk SIG akan ditampilkan (misalnya peta tata letak lembar, format laporan, dll), dan manajemen dan pembatasan keamanan apa yang akan dikenakan pada akses file.

Kegiatan yang dilakukan adalah sebagai berikut :

a. Memilih sumber (dokumen, peta, file digital, dll) untuk setiap entitas dan atribut yangtermasuk dalam diagram Entitas-Relationship.

b. Melakukan pengaturan rancangan basisdata (baik secara logik maupun fisik).

c. Menentukan prosedur untuk mengkonversi data dari media sumber ke basisdata.

d. Menetapkan prosedur untuk mengelola dan memelihara basisdata.

5. Akuisisi Perangkat Keras dan Perangkat Lunak SIG (Acquisition Of GIS Hardware And Software).

Kegiatan perancangan basisdata dilakukan bersamaan dengan aktifitas pemilihan perangkat keras dan perangkat lunak SIG. Perancangan prosedur dan basisdata tidak dapat diselesaikan sebelum hardware dan software SIG telah dipilih sementara pada saat yang sama pemilihan hardware dan software SIG tidak dapat diselesaikan sampai SIG yang dipilih dapat menunjukkan fungsifungsi yang diperlukan pada data. Berdasarkan kemampuan fungsional, dukungan vendor, biaya/fee pemeliharaan, dan survei dari perangkat keras yang tersedia / perangkat lunak, yang telah dibeli, dan semua yang diperlukan renovasi ruang, kabel, dan penataan kembali lingkungan hidup telah dilakukan.

6. Integrasi Sistem SIG berbasis Web (WebGIS System Integration) 
Pada tahap ini proses pengembangan SIG berbasis web, hardware dan software telah diakuisisi dan konversi data telah selesai. Tujuan dari tahap ini kemudian untuk mengintegrasikan komponen yang berbeda dari hardware dan software, untuk menguji dan untuk memastikan seluruh komponen bekerja seperti yang diharapkan, dan untuk memulai semua prosedur yang diperlukan untuk menggunakan SIG.

7. Pengembangan Aplikasi (Application Development)

Pada tahapan ini seluruh kebutuhan dari software yang telah ditentukan dalam tahapan analisa maupun perancangan diwujudkan dalam bentuk aplikasi. Kemudahan untuk digunakan, user friendly, dan volume data transfer menjadi hal yang sangat diperhatikan pada tahap ini. Gambar 3 memperlihatkan antarmuka awal dari aplikasi yang telah dikembangkan (Santosa, 2009).

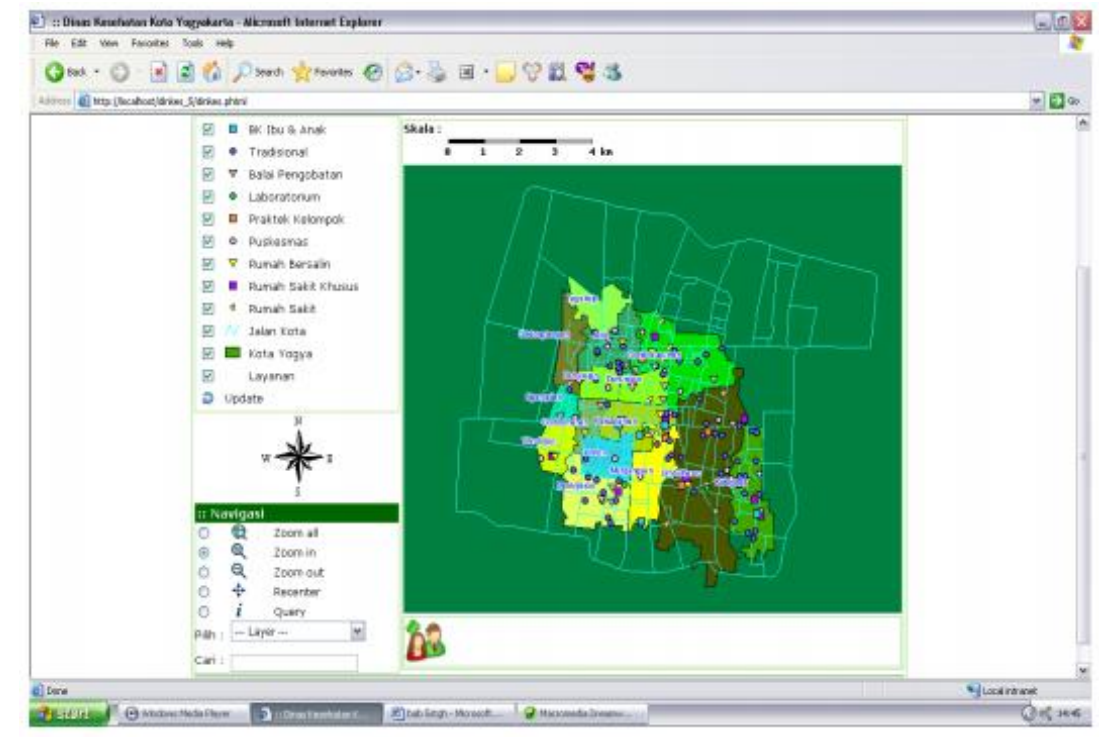

Gambar 3. Antarmuka aplikasi SIG berbasis Web

\section{HASIL DAN PEMBAHASAN}

Berdasarkan rancangan sistem dan database yang penulis buat, maka penulis membuat program berdasarkan data-data yang diterima selama penelitian dan tidak mengalami hambatan-hambatan selama pelaksanaan uji coba ini penulis mendapat kemudahan didalam proses uji coba, berdasarkan hasil uji coba yang dilaksanakan hasilnya sesuai dengan yang diharapkan. 


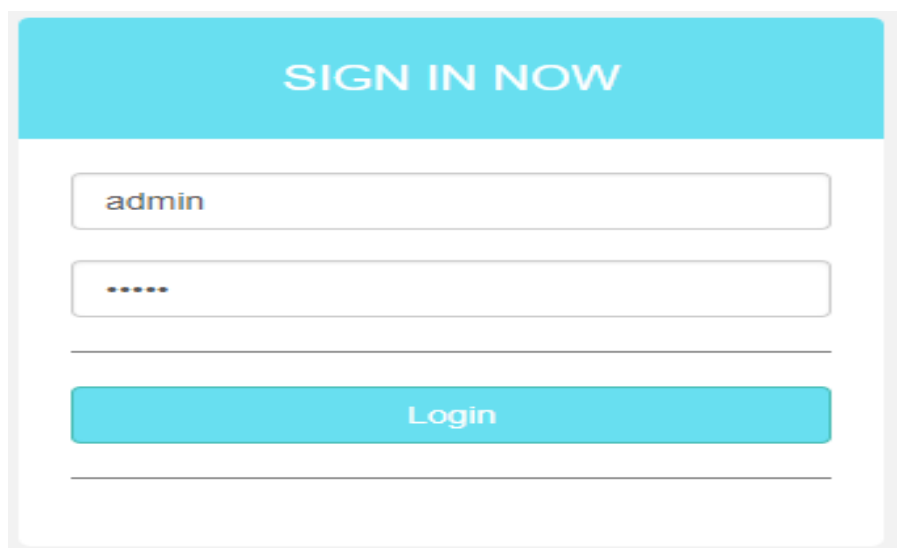

Gambar 4 Menu Login

Langkah pertama yang harus dilakukan untuk dapat menggunakan program aplikasi ini adalah memasukkan user id dan password yang dimiliki dengan benar, kemudian klik ok. Jika username dan password benar, maka program akan menampilkan menu utama. Jika username atau password salah, maka program akan memperingatkan bahwa ada kesalahan dengan username atau password. Jika username atau password masih salah sebanyak tiga kali berturut-turut, maka secara otomatis program aplikasi ini akan tertutup.

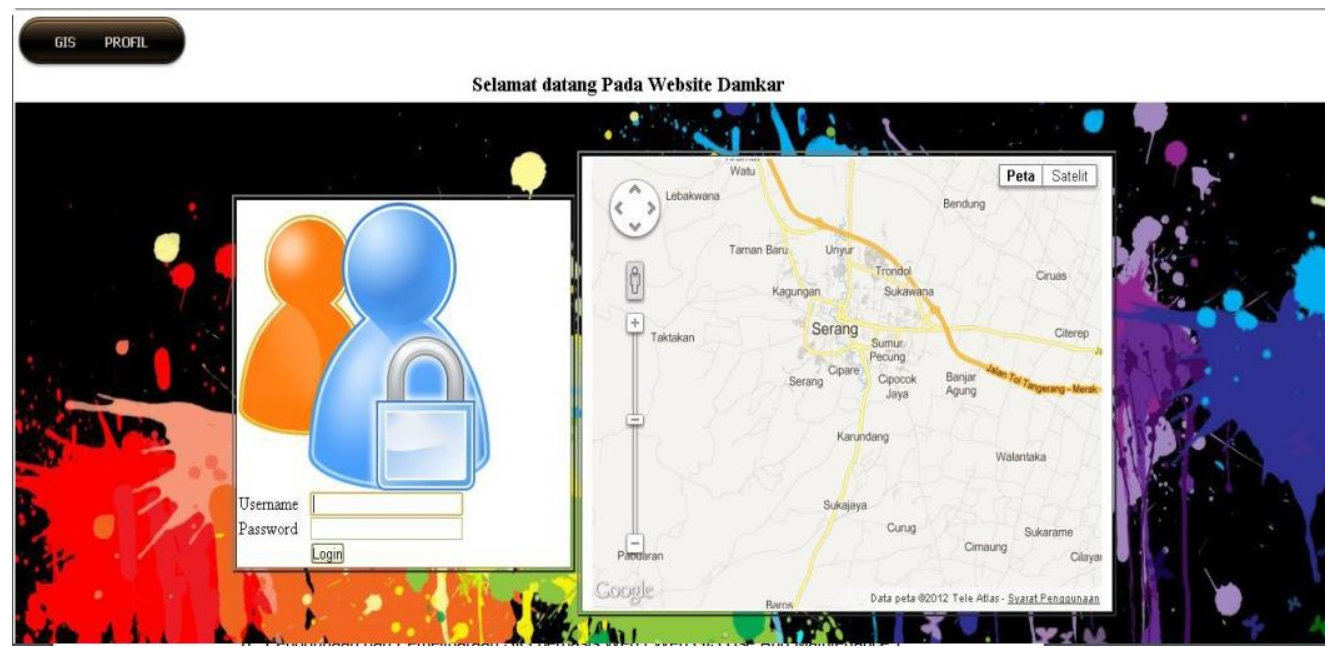

\section{Gambar 5 Menu Utama}

Halaman ini merupakan tampilan awal ketika melakukan pemanggilan program, dimana tampilan ini merupakan tampilan menu utama untuk user, tapi 
apabila seorang admin sistem ingin masuk ke tampilan menu utama admin, maka admin harus login terlebih dahulu dengan menginputkan username dan password pada area login admin di tampilan menu utama user. Kemudian klik tombol Login untuk masuk ke halaman menu utama pada tampilan khusus admin.

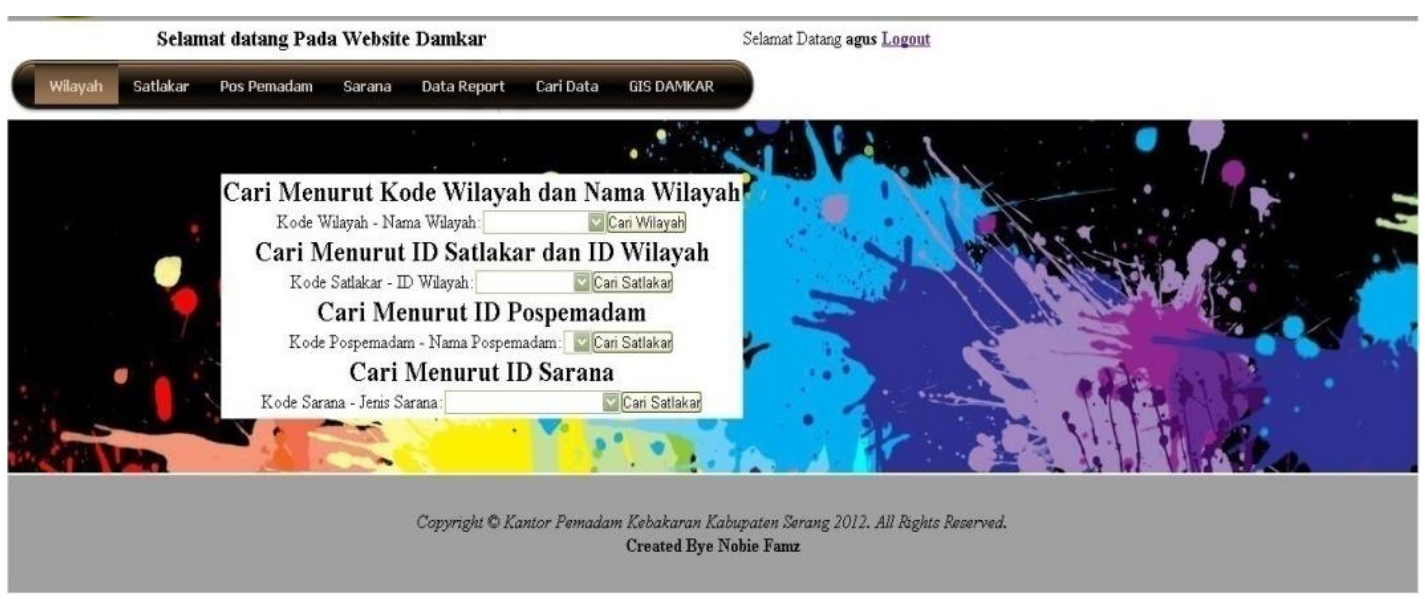

\section{Gambar 6 Form Cari Data}

1. Didalam Form cari data terdapat tombol cari untuk setiap tabel data seperti tabel data wilayah, satlakar, pos pemadam, sarana dan tombol logout untuk keluar dari menu utama admin

2. Jika ingin cari data pada tabel wilayah, maka pilih di cari menurut id wilayah dan nama wilayah, lalu piliah menurut id wilayah dan nama wilayah untuk mencari data pada tabel data wilayah, kemudian klik tombol cari wilayah, maka akan muncul tabel data wilayah, jika tidak maka pilih tombol logout untuk keluar dari menu utama admin. Begitu pula langkah selanjutnya apabila ingin mencari data dari tabel lainnya. 


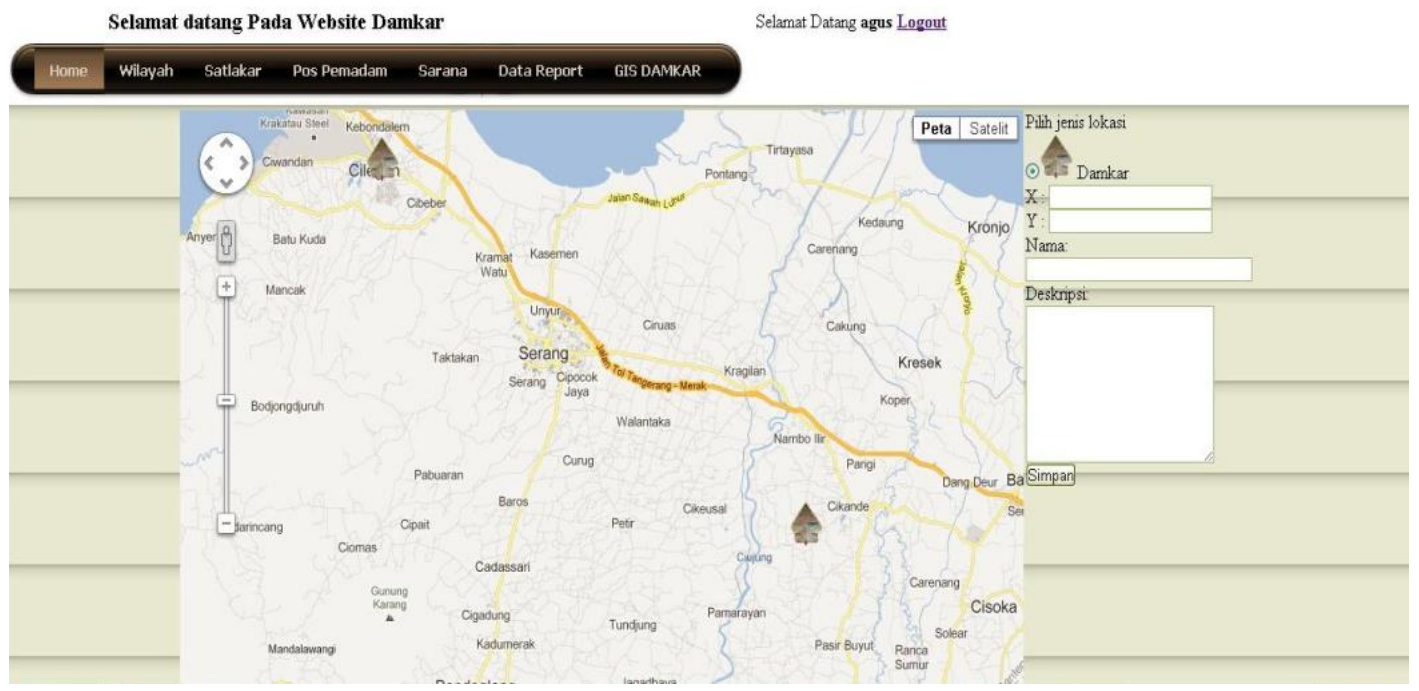

Gambar 7 Form Tampilan SIG

1. Didalam Form GIS damkar terdapat tombol simpan untuk menyimpan data lokasi baru pada peta GIS yang terdiri dari inputan jenis sarana, koordinat X dan Y, nama lokasi dam keterangan tambahan tentang lokasi yang dituju dan tombol logout untuk keluar dari menu utama admin.

2. Jika data yang ingin di simpan sudah di ketikan, maka pilih tombol simpan dan data tersebut akan di masukan pada tabel peta google maps, dan untuk menampilkan hasilnya dibutuhkan koneksi ke internet karena peta berbasiskan google maps.

\section{KESIMPULAN}

1. Pada proses pengelolaan informasi tata letak penyedia sarana pendukung untuk penanggulangan kebakaran, semua data sudah tersimpan dalam database berbasis komputer sehingga penyebaran informasi tata letak sarana pendukung penanggulangan kebakaran saat dibutuhkan oleh petugas pemadam kebakaran yang turun ke lokasi terjadi kebakaran akan lebih cepat didapat sehingga dapat meminimalisir kerugian yang terjadi akibat bencana kebakaran.

2. Semua data sarana pendukung penanggulangan kebakaran yang ada di Kabupaten Serang sudah tersimpan dalam database berbasis komputer, dan pencarian data lokasi sarana dapat teroptimalisasi dengan adanya Sistem 
Informasi Geografis (SIG) yang dapat di akses melalui media internet untuk memudahkan petugas dalam mencari titik lokasi sarana pendukung tersebut

\section{DAFTAR PUSTAKA}

Al-Bahra bin Ladjamudin. 2009. Analisis dan Desain Sistem Informasi. Yogyakarta : Graha Ilmu.

Arief M Rudianto. 2011. Pemrograman Web Dinamis menggunakan PHP dan. $M y S Q L$. Andi. Yogyakarta.

Helali H (2010) Design and Implementation of a Web GIS for the City of Tehran. MSc thesis, Department Of Geodesy And Geomatics Engineering K.N.Toosi University Of Technology, Tehran, Iran.

Jogiyanto.HM, (2009), Konsep Sistem Informasi, Yogyakarta : Andi Publisher.

Santosa, Budi (2009), Web based Application for Mapping of Public Health Services and Facilities, International Industrial Informatics Seminar 2009, UIN Sunan Kalijaga, Yogyakarta.

Budi Santosa,(2011). Pengembangan Perangkat Lunak Sistem Informasi Geografis Berbasis Web, Telematika Vol. 7, No. 2, Januari 2011 : $119-128$. 